\title{
Flight phenology and trap selection for monitoring potential viral vector Aphididae and Aleyrodidae (Hemiptera) in strawberry (Rosaceae) fields of Québec, Canada-ERRATUM
}

\author{
Phanie Bonneau, Jean Denis Brisson, Stéphanie Tellier, and Valérie Fournier
}

https://doi.org/10.4039/tce.2019.15. Published by Cambridge University Press, 10 April 2019.

Owing to a printer's error, the manuscript acceptance date for the article by Bonneau et al. (2019) was listed incorrectly in the printed June 2019 issue of The Canadian Entomologist as well as the original online version of this article. The received, accepted, and online publication dates are as follows:

Received 20 July 2018. Accepted 17 December 2018. First published online 10 April 2019.

This has been corrected online.

We regret the error.

\section{Reference}

Bonneau, P., Brisson, J.D., Tellier, S., and Fournier, V. 2019. Flight phenology and trap selection for monitoring potential viral vector Aphididae and Aleyrodidae (Hemiptera) in strawberry (Rosaceae) fields of Québec, Canada. The Canadian Entomologist, 151: 378-390. https://doi.org/10.4039/tce.2019.15. 